\title{
Vacuum plasma sprayed coatings using ionic silver doped hydroxyapatite powder to prevent bacterial infection of bone implants
}

\author{
Stefanie Guimond-Lischer and Qun Ren \\ Laboratory for Biointerfaces, Empa, Swiss Federal Laboratories for Materials Science \& Technology, \\ Lerchenfeldstrasse 5, CH-9014 St. Gallen, Switzerland \\ Olivier Braissant \\ Department of Urology, University Hospital Basel, Spitalstrasse 21, CH-4031 Basel, Switzerland \\ and Laboratory for Biomechanics and Biocalorimetry, University of Basel, Klingelbergstrasse 50-70, \\ CH-4056 Basel, Switzerland \\ Philipp Gruner \\ Medicoat AG, Gewerbe Nord, CH-5506 Mägenwil, Switzerland \\ Bruno Wampfler and Katharina Maniura-Weber ${ }^{\mathrm{a})}$ \\ Laboratory for Biointerfaces, Empa, Swiss Federal Laboratories for Materials Science \& Technology, \\ Lerchenfeldstrasse 5, CH-9014 St. Gallen, Switzerland
}

(Received 12 January 2016; accepted 23 February 2016; published 10 March 2016)

\begin{abstract}
Fast and efficient osseointegration of implants into bone is of crucial importance for their clinical success; a process that can be enhanced by coating the implant surface with hydroxyapatite (HA) using the vacuum plasma spray technology (VPS). However, bacterial infections, especially the biofilm formation on implant surfaces after a surgery, represent a serious complication. With ever-increasing numbers of antibiotic-resistant bacteria, there is great interest in silver $(\mathrm{Ag})$ as an alternative to classical antibiotics due to its broad activity against Gram-positive and Gramnegative bacterial strains. In the present study, silver ions were introduced into HA spray powder by ion exchange and the HA-Ag powder was applied onto titanium samples by VPS. The Agcontaining surfaces were evaluated for the kinetics of the silver release, its antibacterial effect against Staphylococcus aureus as well as Escherichia coli, and possible cytotoxicity against human bone cells. The HA-Ag coatings with different concentrations of Ag displayed mechanical and compositional properties that fulfill the regulatory requirements. Evaluation of the Ag release kinetic showed a high release rate in the first $24 \mathrm{~h}$ followed by a decreasing release rate over the four subsequent days. The HA-Ag coatings showed no cytotoxicity to primary human bone cells while exhibiting antibacterial activity to E. coli and S. aureus. (C) 2016 American Vacuum Society. [http://dx.doi.org/10.1116/1.4943225]
\end{abstract}

\section{INTRODUCTION}

Despite strict hygienic surgery procedures, bacterial infections occur in $1 \%-2 \%$ of all cases after total hip arthroplasty. ${ }^{1,2}$ Especially for early infections, an antibiotic treatment is typically used to combat any bacterial infection. ${ }^{3,4}$ In severe cases, a prosthesis revision has to be performed that causes not only further discomfort and pain for the patients but also significant medical costs for the healthcare system. ${ }^{1,5,6}$ During the critical postimplantation period, bacterial cells can adhere to the implant-tissue interface, which can lead to colonization and subsequent biofilm formation. ${ }^{7}$ In a biofilm however, due to their encapsulation in extracellular polymer matrix, bacterial cells are more protected against antibiotic treatments, ${ }^{5,8}$ requiring a $50-500$-fold higher concentration of antibiotics to inhibit bacterial growth when compared to planktonic bacteria. ${ }^{8,9}$ Therefore, an implant surface bearing antibacterial properties that prevent bacterial adhesion and further infection could avert infection related problems

\footnotetext{
${ }^{a}$ Author to whom correspondence should be addressed; electronic mail: katharina.maniura@empa.ch
}

following implantation surgeries. Such surfaces can either be antiadhesive and prevent the initial attachment of bacterial cells or be bactericidal, directly causing cell death. ${ }^{10}$ The advantage of the latter approach is that the bactericidal coatings actively counteract an infection through direct contact or through the release of antibacterial agents from the surface. ${ }^{11,12}$ In the case of implant materials, reports on modifying the implant surface with bactericidal agents are manifold, and so are the coating strategies. ${ }^{10}$

Fast initial cell adhesion is crucial for implant stabilization, ${ }^{2,13}$ and hydroxyapatite (HA), which is the major inorganic component of human mineralized tissues such as bone, has been shown to promote a strong binding to the human hard tissue and to enhance osseointegration. ${ }^{13-16}$ HA can be chemically synthesized and shows a crystal structure and chemical composition similar to the natural bone mineral. ${ }^{16,17}$ Importantly, HA displays excellent biocompatibility, bioactivity, osteoconductivity, and nontoxic properties. ${ }^{14,17,18}$ Unfortunately, bulk Ca-P ceramics like HA have poor mechanical properties and cannot be used as implants in stress bearing situations like total joint replacement. ${ }^{19}$ However, coating metal implant surfaces with HA 
has proven to be a useful approach to combine the good mechanical properties of metal implants with the unique bioactive properties of HA. ${ }^{19,20}$

Vacuum plasma spray technology (VPS) is a wellestablished method for the modification of implant surfaces to enhance tissue integration in orthopedics applications. ${ }^{13,15,21}$ This technology enables the deposition of HA onto an implant surface ${ }^{13,15,22}$ with high reproducibility and process efficiency. ${ }^{21,23}$ While HA coated hip endoprosthestic devices have been used for more than 20 years in orthopedic surgery, ${ }^{22}$ plasma spraying has become the most often used technique to produce biocompatible CaP coatings. ${ }^{24}$ For the introduction of antibacterial properties into a coating, it is possible to load HA with bioactive molecules including antibiotics such as vancomycin as well as organic and inorganic bactericides such as chlorhexidine or silver, respectively. ${ }^{20,25}$ However, antibiotics cannot be incorporated during the plasma spraying process because of the high process temperatures, and the dipping method to load antibiotics to calcium phosphate usually results in a burst release of the antibiotics within the first $60 \mathrm{~min}^{25}$ The use of Ag-containing coatings has gained high interest for medical applications due to the ever-increasing number of antibiotic-resistant bacteria strains. ${ }^{10,26,27}$ The Ag ion is well known for its antibacterial activity against Grampositive and Gram-negative bacteria strains, its relatively benign toxicity toward mammalian cells, as well as its thermal stability. ${ }^{10,20,25,28}$

There are several methods to integrate $\mathrm{Ag}$ into $\mathrm{HA}$, including the use of sol-gel technology, ${ }^{5}$ magnetron sputtering, ${ }^{29}$ or microarc oxidation ${ }^{30}$ approaches, that are usually based on the incorporation and later release of Ag nanoparticles. However, the release of such particles can be problematic and a strategy involving ionic silver rather than nanoparticle silver may be favorable for routine clinical use. HA has a very high cation exchange rate with metals like $\mathrm{Zn}, \mathrm{Cu}$, and $\mathrm{Ag},{ }^{31,32}$ and this property can be exploited to directly incorporate $\mathrm{Ag}(\mathrm{I})$ ions into the HA spray powder by replacing $\mathrm{Ca}^{2+}$ ions from the $\mathrm{HA}$ with $\mathrm{Ag}(\mathrm{I})$ ions from an $\mathrm{AgNO}_{3}$ solution.

In this study, we prepared an implant coating based on ionic silver doped HA and evaluated its mechanical properties, cytocompatibility, as well as antibacterial activity. For this, we used HA spray powder that contained $\operatorname{Ag}(\mathrm{I})$ ions and the already existing VPS technology to coat titanium samples to generate an implant surface which, when inserted in the body, is expected to release $\mathrm{Ag}(\mathrm{I})$ ions from the coating to elicit the antibacterial activity. Importantly, the HAAg coating showed compositional and mechanical properties comparable to the native HA coatings. The Ag release kinetics showed an initial burst release, followed by a steady but low release in the subsequent days. Bacterial tests with Gram-positive and Gram-negative bacteria displayed antibacterial effectiveness of the novel coating without a cytotoxic effect on primary human bone cells (HBC), demonstrating the potential value of the ionic silver doped HA coatings for clinical application.

\section{MATERIAL AND METHODS}

\section{A. Preparation of the HA-Ag spray powder}

Commercially available $\mathrm{HA}$ powder (Medicoat AG, Switzerland), with a particle size range from 32 to $45 \mu \mathrm{m}$ was used to manufacture the HA-Ag spray powder. The $\operatorname{Ag}(\mathrm{I})$ ions were incorporated by ion-exchange. In brief, the $\mathrm{HA}$ powder was added into a solution of $\mathrm{AgNO}_{3}$ for $45 \mathrm{~min}$ under constant stirring. To avoid dissolution of HA during the process, the solution was stabilized at $p \mathrm{H} 7$ by the addition of $\mathrm{HNO}_{3}$. After filtration, the powder was dried at $80^{\circ} \mathrm{C}$ for $24 \mathrm{~h}$. Different $\mathrm{AgNO}_{3}$ concentrations were used to obtain different types of HA-Ag powders with $\mathrm{Ag}(\mathrm{I})$ ion concentrations in a range of 900-5000 ppm.

\section{B. Preparation of the HA-Ag coatings}

The HA-Ag coated samples were prepared by Medicoat AG, Switzerland. Two HA-Ag spray powders (900 and $4400 \mathrm{ppm} \mathrm{Ag}$ ) were blended at different ratios to achieve different amounts of $\mathrm{Ag}$ in the coatings (Table I).

Ti6Al4V disks ( $\varnothing 15$ and $\varnothing 25 \mathrm{~mm})$ were used as a substrate for the sample characterization, Ag release, and bacteria experiments. Stainless steel plates $(\varnothing 80 \mathrm{~mm})$ were used as substrates for the cytotoxicity tests. All substrates were grit blasted with medical grade alumina and cleaned in deionized water with ultrasound prior to the coating process. The HA-Ag coatings as well as the control samples with pure HA were applied by VPS. All coatings had a thickness of $100 \pm 25 \mu \mathrm{m}$, as measured with a vernier scale. The crystallinity of the different HA samples was controlled by the energy of the plasma used to spray the samples.

TABLE I. Summary of the HA-Ag coatings used for $\mathrm{Ag}(\mathrm{I})$ release, bacteria, and cytotoxicity tests.

\begin{tabular}{|c|c|c|}
\hline Test & Ag concentration (ppm) & Comments \\
\hline $\operatorname{Ag}(\mathrm{I})$ release in Tris-buffer & $1000^{\mathrm{a}}$ (three and six layer) & High release rate after $24 \mathrm{~h}$ \\
\hline $\mathrm{Ag}(\mathrm{I})$ release in $\mathrm{LB}$ and $\alpha$-MEM & $5000^{\mathrm{a}}$ & High release rate after $24 \mathrm{~h}$ \\
\hline Biofilm inhibition test & $1460^{\mathrm{b}}$ & Inhibited growth of E. coli and S. aureus \\
\hline Isothermal microcalorimetry & $1172,1890^{\mathrm{b}}$ & Longer lag phase for E. coli and S. epidermidis \\
\hline Cytotoxicity assay & $2004,2349,3384^{\mathrm{b}}$ & No cytotoxicity \\
\hline
\end{tabular}

${ }^{\mathrm{a} A g}$ concentration determined in powder before spraying.

${ }^{\mathrm{b}} \mathrm{Ag}$ concentration determined in the coating. 


\section{Release of $\mathbf{A g}(\mathbf{l})$}

The release of $\mathrm{Ag}(\mathrm{I})$ from the HA-Ag coated samples $(\varnothing$ $25 \mathrm{~mm}$ ) in Tris-buffer and different cell culture media was analyzed by inductively coupled plasma optical emission spectrometry (ICP-OES). To assess the dependence of the $\mathrm{Ag}(\mathrm{I})$ release on the coating thickness, HA powder containing $1000 \mathrm{ppm}$ of $\mathrm{Ag}$ was used to spray three and six layered films onto substrates and measurements were performed in Tris-buffer (1 M, $p \mathrm{H}$ 7.4). The substrates coated with HA powder containing $5000 \mathrm{ppm}$ of $\mathrm{Ag}$ were used for measuring $\mathrm{Ag}(\mathrm{I})$ release in lysogeny broth (LB) or cell culture medium $\{$ minimal essential medium ( $\alpha$-MEM, Invitrogen 22561) supplemented with $10 \%$ fetal bovine serum (FBS, Lonza) and $1 \%$ PSN [penicillin $(5 \mathrm{mg} / \mathrm{ml})$, streptomycin $(5 \mathrm{mg} / \mathrm{ml})$, neomycin $(10 \mathrm{mg} / \mathrm{ml})]$ (Gibco 15640)\}, respectively. For all measurements, the samples were placed into six well cell culture plates, covered with $5 \mathrm{ml}$ buffer or media and incubated for $24 \mathrm{~h}$ at $37^{\circ} \mathrm{C}$ on a horizontal shaker. Afterwards the eluates were collected and immediately acidified with concentrated nitric acid to a $p \mathrm{H}$ of 0 . After removal of the liquids, the samples were again covered with new buffer or media, and subjected to further incubation. Each sample was eluted six times. To analyze $\operatorname{Ag}(\mathrm{I})$ by ICP-OES, acidified eluates were treated with microwaves at $500 \mathrm{~W}$ for $10 \mathrm{~min}$. The acidified Tris buffer solutions were analyzed without any further treatment.

\section{Antibacterial test}

\section{Biofilm inhibition test}

To facilitate visualized detection of bacteria, Escherichia coli MG1655 (ATCC47076) and Staphylococcus aureus RN4220 (ATCC35556) carrying the plasmid pCN68 (Ref. 33) with the genes encoding the green fluorescent protein and erythromycin-resistance were used for the biofilm formation studies. The HA and HA-Ag samples $(\varnothing 15 \mathrm{~mm})$ were sterilized at $160^{\circ} \mathrm{C}$ for $2 \mathrm{~h}$, placed at the center of the wells of a 12 -well plate (Corning) and fixed with silicone paste. The samples with the silicone paste were sterilized again with UV light for $1 \mathrm{~h}$ under a BSL2 cabinet.

Overnight cultures performed in LB containing erythromycin $(10 \mu \mathrm{g} / \mathrm{ml}$ for $S$. aureus and $500 \mu \mathrm{g} / \mathrm{ml}$ for E. coli) were diluted within the same medium to optical density $\left(\mathrm{OD}_{600 \mathrm{~nm}}\right)$ of 0.2 for $S$. aureus and 0.1 for E. coli (corresponding to $10^{7}$ colony forming units (CFU)/ml). After dilution, $75 \mu \mathrm{l}$ of these inocula were loaded onto the surface of the fixed samples in the plates. The plates were incubated without shaking for $2 \mathrm{~h}$ (E. coli) or $6 \mathrm{~h}$ (S. aureus) at room temperature to allow cell attachment. Afterwards the bacterial culture liquid was removed, and the samples were washed three times with phosphate buffered saline (PBS) to remove loosely attached cells from the sample surfaces. A volume of $1.5 \mathrm{ml}$ fresh medium $[0.25 \%$ glucose, $0.2 \%$ $\left(\mathrm{NH}_{4}\right)_{2} \mathrm{SO}_{4}$, and $\left.1 \% \mathrm{LB}\right]$ containing erythromycin $(10 \mu \mathrm{g} / \mathrm{ml}$ for $S$. aureus and $500 \mu \mathrm{g} / \mathrm{ml}$ for $E$. coli) was added into the wells. The whole plate was sealed with parafilm to prevent medium evaporation, and placed in rotating incubator
( $80 \mathrm{rpm}$ ) at $37^{\circ} \mathrm{C}$. After $24 \mathrm{~h}$, the samples were washed three times with PBS, and the cell attachment and biofilm formation on the surface of the samples was analyzed by fluorescent microscopy (Leica DFC350 FX, Leica Microsystems, Heerbrugg, Switzerland). Excitation was at $450-490 \mathrm{~nm}$, and green fluorescence was detected at $525-550 \mathrm{~nm}$. The experiments were performed in triplicates.

\section{Isothermal microcalorimetry}

To monitor growth and metabolic activity of biofilm on surfaces, isothermal microcalorimetry was chosen to perform the antibacterial assays. For isothermal microcalorimetry, the HA and HA-Ag samples (Ø $15 \mathrm{~mm}$ ) were sterilized with UV light for 30-45 min under a BSL2 cabinet. Briefly, E. coli ATCC25922 and S. epidermidis ATCC49461 were grown in LB and diluted to obtain a final concentration of $1 \times 10^{7} \mathrm{CFU} / \mathrm{ml}$. A volume of $10 \mu$ l of this bacterial suspension was then spread onto the surface of the HA coating. After this, the inoculum was absorbed by the HA layer, the samples were placed aseptically into a microcalorimetric vial containing LB agar with the HA layer facing the agar (sample lays upside-down). This setup enhances the formation of a biofilm between the solid medium and the sample surface. The microcalorimetric vials were then closed and introduced into the microcalorimeter (TAM air, Waters/TA, DE). Metabolic heat production was recorded after thermal equilibration was achieved (usually within $1-2 \mathrm{~h}$ ) until it returned to baseline level, indicating no further bacterial activity.

Using the microcalorimetric data, the maximum growth rate $\left(\mu_{\max }\right)$, the lag phase duration $(\lambda)$, and the amount of heat produced $\left(\mathrm{Q}_{\mathrm{tot}}\right)$ were estimated by fitting the Gompertz equation to the integrated heat over time curve. ${ }^{34,35}$ All calculations were made using $\mathrm{R}$ and the grofit package. ${ }^{36,37}$ Using the calculated growth rate, the doubling time (Td) is obtained easily as $T d=\ln _{2} /$ growth rate. Dividing the difference in lag phase duration between the control and the treated samples by the doubling time reflects the number of doublings $(\mathrm{Nd})$ that took place during this time. Using the expression $\left[1 /\left(2^{\mathrm{Nd}}\right)\right] \times 100$, the survival rate (in percentages) is obtained.

\section{E. Cell culture procedures}

HBC were isolated from femur-derived human bone marrow samples that were obtained during surgical hip replacement of otherwise healthy patients after having received informed consent. The protocol was approved by the ethical board of the Kantonsspital St. Gallen, Switzerland (ethical committee approval number EKSG 08/014/1B). Bone marrow samples were incubated in a $20 \mathrm{ml}$ isolation medium $[25 \mathrm{mM}$ 4-(2-hydroxyethyl)-1-piperazineethanesulfonic acid (HEPES) (Fluka 54459), $128.5 \mathrm{mM} \mathrm{NaCl}$ (Fluka 71380), $5.4 \mathrm{mM} \mathrm{KCl}$ (Fluka 60130), $5.5 \mathrm{mM} \mathrm{D(+)-glucose} \mathrm{(Sigma} \mathrm{G7528),}$ $51.8 \mathrm{mM} \mathrm{D}(+)$-saccharose (Fluka 84097), and 0.1\% BSA (Sigma A6003)] overnight at $4{ }^{\circ} \mathrm{C}$. Afterwards the samples were centrifuged at $110 \times g$ for $15 \mathrm{~min}$ at $4^{\circ} \mathrm{C}$. The retained 
trabecular bone pieces were rinsed repeatedly under microscopic observation with isolation media to the remaining tissues, fat, and blood cells. Five to ten pieces of bone with a total weight of approximately $25 \mathrm{mg}$ were placed into a T75 culture flask (Cellstar T75, Greiner Bio-One GmbH, Frickenhausen, Germany) and cultivated in $\alpha$-MEM medium supplemented with $10 \%$ FBS, $1 \%$ PSN, and $1 \mathrm{ng} / \mathrm{ml}$ human basic fibroblast growth factor (FGF-2, Sigma F0291) in a humidified incubator at $37^{\circ} \mathrm{C}$ with $5 \% \mathrm{CO}_{2} / 95 \%$ air. After approximately three weeks, cells reached $70 \%$ confluency and were directly used for the experiments.

\section{F. Cytotoxicity assay}

The cytotoxicity assay was performed according to the ISO-norm 10993-5 to determine if the test materials release toxic substances that have negative effects to cells in culture. For this assay, the HA and HA-Ag coatings were sprayed onto stainless steel plates $(\varnothing 80 \mathrm{~mm})$. After the sterilization process $\left(160^{\circ} \mathrm{C}\right.$ for $\left.2 \mathrm{~h}\right)$, the plates were briefly washed with sterile water once and then covered with culture medium $(\alpha-$ MEM, $1 \%$ PSN, $1 \mathrm{ng} / \mathrm{ml} \mathrm{FGF-2)} \mathrm{at} \mathrm{a} \mathrm{ratio} \mathrm{of} 3 \mathrm{~cm}^{2} / \mathrm{ml}$ and subsequently incubated at $37^{\circ} \mathrm{C}, 5 \% \mathrm{CO}_{2}$ for $72 \mathrm{~h}$. Subsequently, the obtained extract solution was diluted with fresh culture medium incubated under the same conditions to achieve different extract concentrations $(94,50,20,10$, and 0 vol. \%); fetal bovine serum (FCS) and PSN were added freshly. The extract solutions with different concentrations were added to HBCs ( 7000 cells per 24 well, preseeded $24 \mathrm{~h}$ before) and cultures were then incubated at $37^{\circ} \mathrm{C}$ and $5 \%$ $\mathrm{CO}_{2}$ for 5 days. As a positive control, different concentrations of a $\mathrm{CdSO}_{4}$ solution $\left(\mathrm{CdSO}_{4} \times 8 / 3 \mathrm{H}_{2} \mathrm{O}\right.$, Sigma 20920) were added to the cell culture.

The effect on cell proliferation was determined by deoxyribonucleic acid (DNA) assay using the Hoechst 33258 assay (Sigma 861405) as described previously. ${ }^{38}$ Briefly, the culture medium was removed and $250 \mu \mathrm{l}$ distilled water per well was added to lyse the cells. After incubation at $37^{\circ} \mathrm{C}$ for $60 \mathrm{~min}, 250 \mu \mathrm{l}$ of Hoechst solution $[20 \mu \mathrm{g} / \mathrm{ml}$ in TNE $(10 \mathrm{mM}$ Tris, $2 \mathrm{M} \mathrm{NaCl}$, and $1 \mathrm{mM}$ ethylenediaminetetraacetic acid) buffer] was added to the cells and incubated for further $60 \mathrm{~min}$ on a horizontal shaker at room temperature. Thereafter, fluorescence was measured at $460 \mathrm{~nm}$. The wells without cells were used as blanks.

The effect on mitochondrial activity was analyzed by MTT [3-(4,5-dimethylthiazol-2-yl)-2,5-diphenyltetrazolium bromide] assay. ${ }^{39}$ The MTT assay was performed as described previously. ${ }^{40}$ Briefly, the wells were washed once with pure $\alpha$-MEM. MTT stock solution of $125 \mu \mathrm{l}$ $(5 \mathrm{mg} / \mathrm{ml} \mathrm{MTT} \mathrm{in} \mathrm{PBS)} \mathrm{were} \mathrm{added} \mathrm{to} \mathrm{each} \mathrm{well} \mathrm{and} \mathrm{incu-}$ bated at $37^{\circ} \mathrm{C}$ for $60 \mathrm{~min}$. After this incubation time, the medium was discarded, and $500 \mu \mathrm{l}$ solvent solution [ $90 \%$ ethanol, 10\% HEPES (50 mM)- $\mathrm{NaCl}(50 \mathrm{mM}), p \mathrm{H} 8.0]$ was added to each well. The plates were incubated on a horizontal shaker for $15 \mathrm{~min}$, and the optical density was measured at $550 \mathrm{~nm}$ (Biotec Instruments Elx800, Witec AG,
Littau, Switzerland). The wells without cells were used as blanks.

The experiments were performed in triplicates. Significant effects $(\mathrm{p}<0.05)$ were determined using the two way analysis of variance (ANOVA) with Dunn-Bonferroni posthoc test (s PLus software).

\section{G. Coating characterization}

The sprayed HA coatings were analyzed by x-ray diffraction (XRD) for crystallinity according to ISO 13779-3. In brief, the XRD was measured with a Siemens D5000 with a $\mathrm{Cu}$ X-ray source, and the measurements were conducted from $2 \theta=20^{\circ}-60^{\circ}$ with a step size of $0.02^{\circ}$ with a $4 \mathrm{~s}$ pause at each step. The coating adhesion strength was measured according to ISO 13779-4 with a Walter + Bai LFV-150 kN PM-SOP 2472 uniaxial tensile tester. For these measurements, the samples ( the fixture of the testing machine using a FM1000 adhesive film.

\section{RESULTS}

\section{A. Release of $\mathbf{A g}(\mathbf{l})$}

\section{Ag(I) release in dependence of the coating thickness}

To evaluate the dependence of the $\operatorname{Ag}(\mathrm{I})$ release on the thickness of the HA layer, coatings with different thicknesses (three and six-layered) were incubated in $1 \mathrm{M}$ Tris buffer before assessing the $\mathrm{Ag}(\mathrm{I})$ release kinetics [Fig. 1(a)].

$\mathrm{Ag}(\mathrm{I})$ release of the six-layered samples was highest at the beginning of the incubation $(7.1 \mu \mathrm{g} / 24 \mathrm{~h})$ and decreased continuously during 4 days until it reached a nearly constant value of $0.2-0.4 \mu \mathrm{g} / 24 \mathrm{~h}$. The decrease can be approximated using a second order exponential decay function [Fig. 1(a)]. The total release per sample over the period of 15 days was determined to be $12.6 \mu \mathrm{g}$. Duplicate measurements only differed by $0.3 \mu \mathrm{g}$. The $\mathrm{Ag}(\mathrm{I})$ release of the three-layered samples showed similar pattern but was found to release about half amount of the Ag when compared to the six-layered ones. The total release of the three-layered samples was $6.6 \mu \mathrm{g}$. Again, the duplicate measurements showed a good reproducibility and only differed by $0.45 \mu \mathrm{g}$.

\section{Influence of different media on the $A g(I)$ release}

To evaluate the influence of different media on the release of $\mathrm{Ag}(\mathrm{I})$ from the HA-Ag coatings, samples were incubated with $\alpha$-MEM $+10 \%$ FCS, or with LB-medium before assessing $\operatorname{Ag}(\mathrm{I})$ release kinetics [Fig. 1(b)]. The $\mathrm{Ag}(\mathrm{I})$ release in $\alpha-\mathrm{MEM}+10 \% \mathrm{FCS}$ was highest at the beginning of the experiment $(3 \mu \mathrm{g} / 24 \mathrm{~h})$ and also decreased continuously during 4 days before reaching values close to or below the determination limit of $0.25 \mu \mathrm{g} / 24 \mathrm{~h}$. In LBmedium, similar initial release characteristics with an $\mathrm{Ag}(\mathrm{I})$ release of $2.6 \mu \mathrm{g} / 24 \mathrm{~h}$ was observed after the first $24 \mathrm{~h}$. However, the release decreased slowly and reached a 

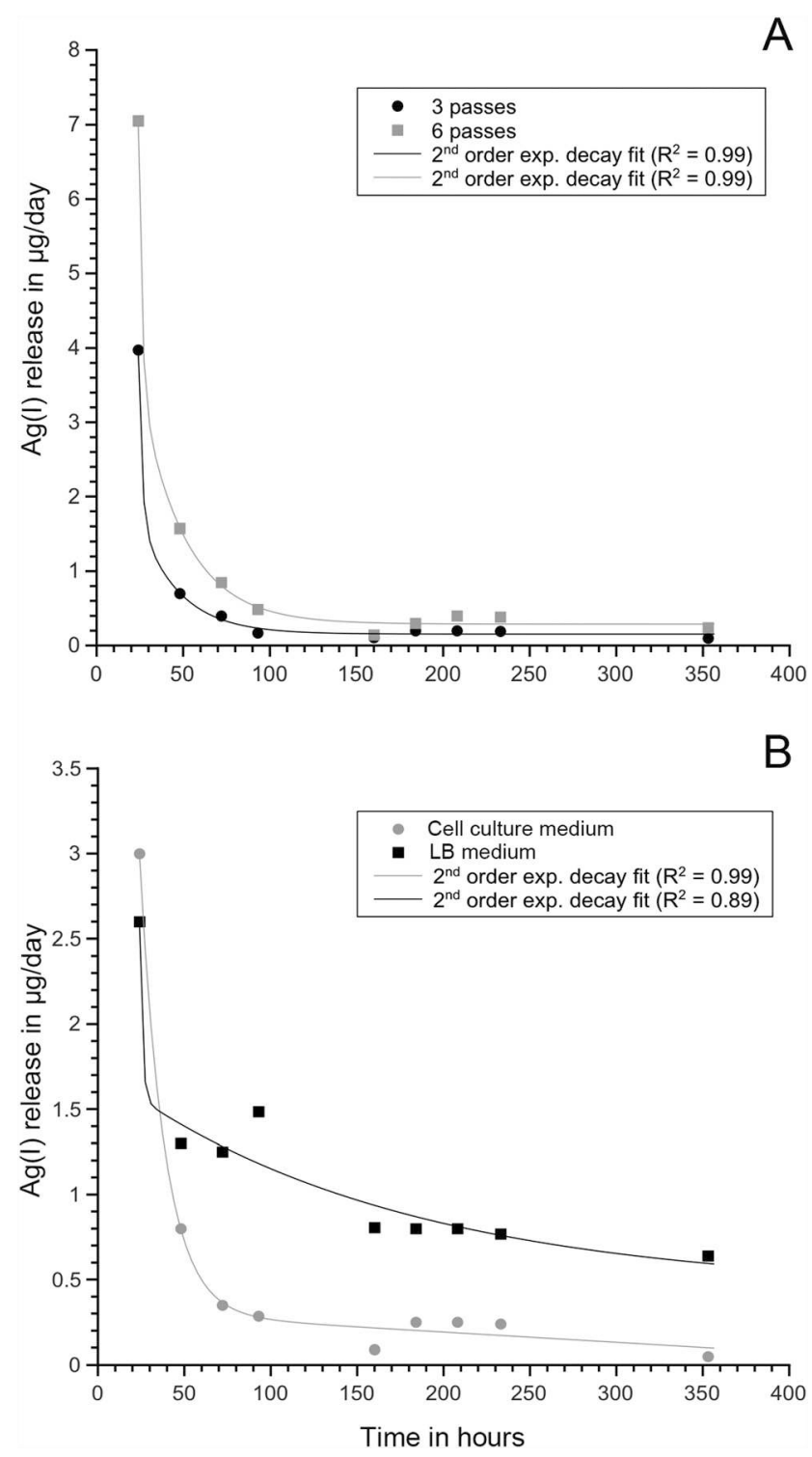

FIG. 1. (a) Release of $\mathrm{Ag}(\mathrm{I})$ for different coating thicknesses in Tris-buffer. HA-Ag powder of $1000 \mathrm{ppm}$ was used to spray three (circles) and six (squares) coating layers. (b) Release of $\mathrm{Ag}(\mathrm{I})$ from coatings sprayed with $5000 \mathrm{ppm}$ HA-Ag powder in the cell culture medium $(\alpha-\mathrm{MEM}+10 \%$ FCS $)$ (circles) and LB-medium (squares).

constant value of $0.8 \mu \mathrm{g} / 24 \mathrm{~h}$ after 4 days. The release in both $\alpha$-MEM $+10 \%$ FCS and LB medium can be approximated by a second order exponential decay function [Fig. $1(\mathrm{~b})$ ]. In contrast, no Ag could be detected in $\alpha$-MEM without FCS (results not shown).

\section{B. Antibacterial test}

\section{Qualitative assessment of biofilm inhibition}

To assess the inhibitory effect of the HA-Ag coating on biofilm formation, samples having a crystallinity of approximately $56 \%$ and different $\mathrm{Ag}$ concentrations of 1460-2400 ppm were seeded with $E$. coli and $S$. aureus cells, and bacterial growth was evaluated by fluorescence microscopy (Fig. 2). Ag-free samples that were used as control were completely covered by bacterial cells and exhibited a strong green fluorescence. On the

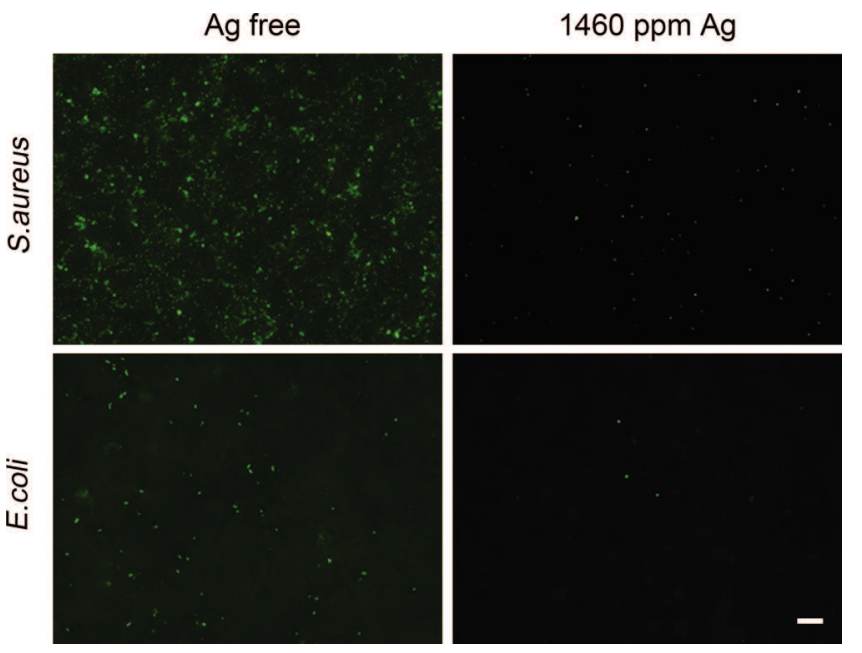

FIG. 2. Fluorescence microscopic images of $S$. aureus and E. coli bacteria attached to the HA and HA-Ag coatings having $1460 \mathrm{ppm} \mathrm{Ag.} \mathrm{Cells} \mathrm{were}$ incubated in the presence of the samples; samples were washed after $24 \mathrm{~h}$ and imaged. Scale bar: $20 \mu \mathrm{m}$.

contrary, the samples containing $1460 \mathrm{ppm} \mathrm{Ag}$ inhibited the growth of both $E$. coli and $S$. aureus, resulting in only sparsely populated HA-Ag surfaces.

\section{Quantitative assessment to determine the antibacterial effect of HA-Ag coating}

To quantitatively assess the inhibitory effect of the HA-Ag coating on bacterial growth, isothermal microcalorimetry was employed. The results are summarized in Table II. On substrates coated with HA-Ag, the growth rates of and the metabolic heat produced by E. coli and S. epidermidis were not significantly different from those populations cultivated on surfaces coated with pure HA. However, the lag phase duration was significantly longer on the HA-Ag coated samples. Remarkably, no significant differences were found between the high and the low $\mathrm{Ag}$ concentration in the samples.

\section{Extract test to evaluate the cytotoxicity of the HA-Ag coatings to primary human bone cells}

To evaluate possible cytotoxic effects of the HA-Ag coatings, HBCs were subjected to different concentrations of material extracts obtained from coatings with selected concentrations of $\mathrm{Ag}$ and cell viability as well as metabolic activity was quantitatively assessed. The Ag-free HA coatings were used as controls and a reduction of $30 \%$ in cell viability or proliferation compared to the control cells is defined as the threshold for an extract to be considered toxic. $^{41}$ The stainless steel plates without coatings were previously tested and showed no cytotoxic effects on HBCs (data not shown). The cell proliferation and cell viability were not negatively affected by the HA coatings, but HA actually resulted in increasing activity values and DNA content with increasing extract concentration (Fig. 3). Notably, different crystallinity of the coatings had no significant influence on cell proliferation and activity. 
TABLE II. Growth parameters and calculated survival rates of the inocula for S. epidermidis and E. coli.

\begin{tabular}{|c|c|c|c|c|c|c|}
\hline Coating type & Ag content in coating (ppm) & Growth rate $\left(\mathrm{h}^{-1}\right)$ & Lag phase duration (h) & Metabolic heat produced $(\mathrm{J})$ & Survival rate ${ }^{\mathrm{a}}(\%)$ & $\mathrm{n}$ \\
\hline \multicolumn{7}{|l|}{ S. epidermidis } \\
\hline Pure HA & 0 & $1.23 \pm 0.07$ & $15.42 \pm 2.67$ & $64.03 \pm 7.92$ & & 6 \\
\hline HA-Ag & 1172 & $1.30 \pm 0.38$ & $23.76 \pm 6.79^{c}$ & $59.11 \pm 6.63$ & $<0.001 \%$ & 9 \\
\hline HA-Ag & 1890 & $1.16 \pm 0.31$ & $25.60 \pm 10.28^{c}$ & $60.94 \pm 4.97$ & $<0.001 \%$ & 9 \\
\hline \multicolumn{7}{|l|}{ E. coli } \\
\hline Pure HA & 0 & $3.67 \pm 0.43$ & $7.20 \pm 0.76$ & $70.33 \pm 6.17$ & & 6 \\
\hline $\mathrm{HA}-\mathrm{Ag}$ & 1172 & $2.88 \pm 0.34^{\mathrm{b}}$ & $9.21 \pm 1.36^{\mathrm{c}}$ & $73.91 \pm 5.36$ & $0.3 \%$ & 9 \\
\hline HA-Ag & 1890 & $3.11 \pm 0.57$ & $10.73 \pm 2.88^{\mathrm{c}}$ & $72.69 \pm 2.98$ & $<0.001 \%$ & 9 \\
\hline
\end{tabular}

${ }^{a}$ Value for survival rate calculated using the growth rate and the differences in lag phase duration (see Sec. II for details).

${ }^{\mathrm{b}}$ Significant differences between the HA and HA-Ag samples with $p=0.05$ for t-test.

${ }^{\mathrm{c}}$ Significant differences between the HA and HA-Ag samples with $p<0.01$ for t-test.

Interestingly, while incorporation of $\mathrm{Ag}(\mathrm{I})$ ions into the HA coatings had no negative effect on the metabolic activity and proliferation of $\mathrm{HBCs}$ at all concentrations tested, the cell promoting effect of the HA coating with $70 \%$ crystallinity was diminished by the amount of 3384 ppm Ag (Fig. 3). The highest extract concentrations (50\% and 94\%) of the HA coating with $3384 \mathrm{ppm} \mathrm{Ag}$ showed significantly reduced cell proliferation and viablity when compared to the extracts of the HA coatings with 2004 or 2349 ppm Ag. While the HA coatings containing 2004 and 2349 ppm of Ag still promotes cell viability, $3384 \mathrm{ppm}$ Ag inhibits cell activity and proliferation but showed no toxic effect according to ISOnorm 10993-5, when compared to control cells.

\section{Characterization of HA-Ag coating using uniaxial tensile tests and XRD}

To assess the mechanical properties and composition of the novel HA-Ag coatings, uniaxial tensile tests as well as $\mathrm{XRD}$ analysis were performed, respectively. The HA-Ag coatings showed similar adhesion forces when compared with the pure HA coatings, both being well above the required adhesion force according to the ISO-Norm 13779-2 [see supplementary Fig. 1(a)]. ${ }^{42}$ The XRD analysis could not detect any impurity phases of tetracalcium phosphate (TTCP), tricalcium phosphate $(\mathrm{TCP})$, or calcium oxide $(\mathrm{CaO})$ [see supplementary Fig. 1(b)].
HA
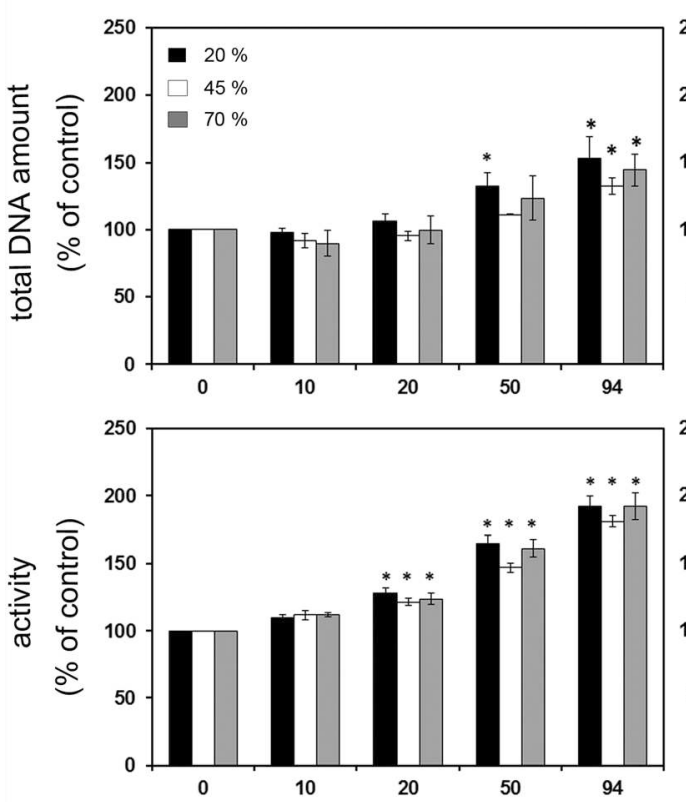

$\mathrm{HA}-\mathrm{Ag}$
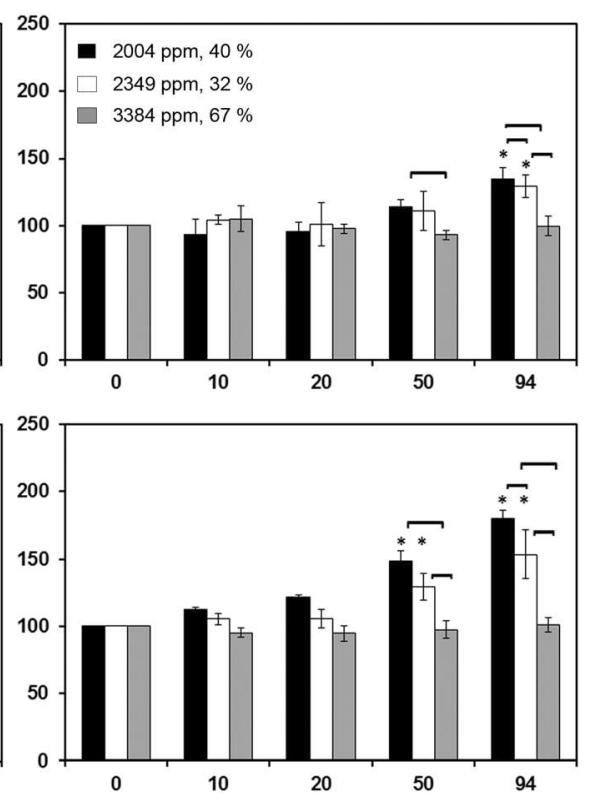

extract concentration (\%)

FIG. 3. Cytotoxicity assay of the HA and HA-Ag coatings with 2004, 2349 and 3384 ppm Ag, respectively, as determined by DNA and MTT measurements on day 5. The data are expressed as mean \pm s.e.m. of three independent experiments. * indicate significant differences to control cells (no extract) $(p<0.05)$, square brackets indicate significant differences between samples with crystallinity or amount of Ag $(p<0.05)$ determined using the two way ANOVA with Dunn-Bonferroni posthoc test. 


\section{DISCUSSION}

Despite strict hygienic procedures during implant surgeries, the problem of bacterial infections still persists, ${ }^{2,27,43}$ with Gram-positive strains S. epidermidis and S. aureus and the Gram-negative strain E. coli being the most common strains to cause implant infections. ${ }^{26}$ In fact, $S$. epidermidis and $S$. aureus are pathogens that cause most nosocomial infections ${ }^{44-47}$ and since 1980 , up to $60 \%$ of all prosthetic hip implant infections have been associated with Staphylococcus species. ${ }^{26}$ Therefore, after a total hip arthroplasty, patients routinely receive an antibiotic treatment to prevent postsurgical infections. ${ }^{25}$ However, the administration of antibiotics exhibits disadvantages such as a low drug concentration at the implant site, potential intolerances of the patient, as well as fostering the creation and spreading of antibiotic resistant bacterial strains. ${ }^{25-27}$

Therefore, the HA-Ag coated titanium implants were produced using the VPS technology with the promise to decrease the initial attachment of bacteria to the implant material while enhancing the tissue integration due to the bioactive properties of HA. The main advantage of $\mathrm{Ag}$ releasing coatings over oral administration of antibiotics is the direct localization at the target site. While coatings that contain metallic Ag are not efficient because Ag has to be in its oxidized form $[\mathrm{Ag}(\mathrm{I})]$ to show antibacterial activity, ${ }^{26,27}$ the ion exchange process can be exploited to produce HA powder with incorporated $\operatorname{Ag}(\mathrm{I})$ ions and depending on the ion exchange parameters, it is also possible to create powders with different amounts of Ag. Recently, silver ion doped calcium phosphate nanopowders were used to produce antibacterial coatings on titanium implants via electrospraying. ${ }^{48}$ In the present study, the benefit of the VPS process is that the HA-Ag powder forms a continuous ceramic film on the implant material in an industrially established process. Once the implant with an antibacterial coating is inserted in the body, $\operatorname{Ag}(\mathrm{I})$ ions are expected to be released from the coating to inhibit bacterial cell growth. ${ }^{49} \mathrm{Ag}(\mathrm{I})$ ions exert their broad antimicrobial effect by interacting with the bacterial cell membrane, proteins, and enzymes, as well as by hindering DNA replication. ${ }^{10,50,51}$ However, bacteria can acquire an $\mathrm{Ag}$ resistance, ${ }^{27,52}$ and it is therefore of paramount importance to avoid bacterial adaptation to Ag when exposing bacterial cells continuously to high Ag content. An ideal antibacterial coating should thus provide a high Ag release during the first $6 \mathrm{~h}$ postimplantation that is prone for bacterial attachment, followed by a continuous, but low concentration Ag release for a sustained antibacterial effect. ${ }^{26,27}$ The herein investigated HA-Ag coatings revealed a high Ag release in the first $24 \mathrm{~h}$ followed by a low continuous release during the subsequent days. The dependence of the $\mathrm{Ag}$ release on the coating thickness furthermore showed that $\mathrm{Ag}$ is uniformly distributed in and released from the whole coating and not only from the surface (Fig. 1). As bacteria and human cells grow under different culture conditions, release kinetics for different cell culture media and buffers were assessed. While $\alpha$-MEM supplemented with $10 \%$ FCS and
LB are not ideal solutions for the investigation of $\mathrm{Ag}(\mathrm{I})$ release, due to the influence of precipitation and redox reactions on the concentration of dissolved $\mathrm{Ag}(\mathrm{I})$, Tris buffer was found to have ideal properties for Ag-release measurements. Nevertheless, Ag release kinetics showed the same trend in all conditions. As the cell culture medium is actually similar in composition to what can be encountered in the body, it can be presumed that the HA-Ag coatings exhibit the desired high Ag burst release during the critical postimplantation period. The surprisingly low concentration of $\mathrm{Ag}(\mathrm{I})$ in $\alpha$-MEM can be explained by the presence of ascorbic acid. Ascorbic acid reduces $\operatorname{Ag}(\mathrm{I})$ to insoluble $\operatorname{Ag}(0)$ at ambient temperature, thus resulting in the formation of poorly soluble nanoparticles. ${ }^{53}$ The reduction of $\mathrm{Ag}(\mathrm{I})$ might also occur in $\alpha$-MEM supplemented with $10 \%$ FCS, but FCS contains proteins that stabilize $\operatorname{Ag}(\mathrm{I})$ partially by complexation. $^{53}$ The measurements of $\mathrm{Ag}(\mathrm{I})$ in the $\mathrm{LB}$ medium revealed lower maximum and higher long-term concentrations compared to the values found in Tris buffer [Fig. 1(a)]. This suggests partial precipitation of an $\mathrm{Ag}$ compound during the release, for example, as $\mathrm{AgCl}$, which remained with the samples when the solutions were changed. When fresh LB solution was added, a fraction of the $\mathrm{AgCl}$ was dissolved until a dynamic equilibrium was reached.

The antibacterial effectiveness of the HA-Ag coatings was determined using the Gram-positive strain S. epidermidis and $S$. aureus and the Gram-negative strain E. coli, and the HA-Ag coatings with an Ag content of $1172 \mathrm{ppm}$ (Table II) showed an efficient antimicrobial effect against both bacterial species. Although it is generally accepted that Gram-positive bacteria are better protected against antibacterial agents by the thicker layer of peptidoglycan, our study shows similar efficiency on both Gram-negative and -positive microorganisms. As Ag acts as a bactericidal agent, the growth rates and metabolic heat production of bacteria grown on the HA-Ag coatings measured by the isothermal microcalorimetry were not affected, only the lag phase duration was longer, thus indicating that only a fraction of the inoculum survived the exposure to HA-Ag and was able to regrowth. The lack of difference between the high and low $\mathrm{Ag}$ concentration is also consistent with the previous observation made during the $\mathrm{Ag}$ release measurements in the $\mathrm{LB}$ medium [i.e., $\operatorname{Ag}(\mathrm{I})$ concentration reaches an equilibrium in the medium]. Most probably, the concentration of free silver ions cannot be above a certain equilibrium value. Unfortunately, it is rather complex to determine the exact concentration in LB medium.

Since HA alters during incubation in culture media and precipitation of calcium phosphate crystals occurs, ${ }^{54}$ direct cell seeding onto the coatings is not straightforward and more importantly not useful to investigate interactions of human cells with the HA-Ag surface. ${ }^{18}$ Therefore, the in vitro extract assay according to ISO-norm 10993-5 was employed to evaluate the effect of the HA-Ag coatings on human bone cells, revealing that the HA-Ag coatings with an $\mathrm{Ag}$ content of up to $3384 \mathrm{ppm}$ are cytocompatible, indirectly suggesting that initial cell adhesion to the implant 
surface in the body should not be hampered. The HA-Ag coatings containing up to $2349 \mathrm{ppm} \mathrm{Ag}$ even promote cell proliferation and activity.

\section{CONCLUSION}

This study shows that the industrially used VPS technology can be employed to produce the HA-Ag coatings on titanium implants to generate an antibacterial surface for implant materials, which has great potential to reduce the incidence of bacterial infections in orthopedic surgery.

\section{ACKNOWLEDGMENTS}

The Commission for Technology and Innovation "CTI Medtech" is acknowledged for financial support of the project under the Contract No. 9071.1 PFLS-LS. The authors thank Christopher R. Bradbury for his help with the coating characterization. They thank Kathrin Grieder for her technical help with the Ag release measurements and the bacterial tests and Songhak Yoon for his help with the XRD measurements. The authors are grateful to Hans-Beat Mosimann and Bernhard Von Gurten for their assistance with the sample preparation and measurements. They also thank Gernot Bonkat and Dieter Wirz for valuable discussion and inputs.

${ }^{1}$ P. Cherubino, M. Puricelli, and F. D'Angelo, Open Orthop. J. 7, 190 (2013). ${ }^{2}$ H. J. Busscher, H. C. van der Mei, G. Subbiahdoss, P. C. Jutte, J. J. A. M. van den Dungen, S. A. J. Zaat, M. J. Schultz, and D. W. Grainger, Sci. Transl. Med. 4, 153rv10 (2012).

${ }^{3}$ K. S. N. Anagnostakos, J. Kelm, U. Grün, and J. Jung, Int. J. Med. Sci. 6, 227 (2009).

${ }^{4}$ B. Fink, Int. J. Med. Sci. 6, 287 (2009).

${ }^{5}$ W. Chen, S. Oh, A. P. Ong, N. Oh, Y. Liu, H. S. Courtney, M. Appleford, and J. L. Ong, J. Biomed. Mater. Res., Part A 82, 899 (2007).

${ }^{6}$ I. Uçkay, P. Hoffmeyer, D. Lew, and D. Pittet, J. Hosp. Infection 84, 5 (2013).

${ }^{7}$ V. Stanic, D. Janackovic, S. Dimitrijevic, S. B. Tanaskovic, M. Mitric, M. S. Pavlovic, A. Krstić, D. Jovanović, and S. Raičević, Appl. Surf. Sci. 257, 4510 (2011).

${ }^{8}$ K. D. Secinti, H. Özalp, A. Attar, and M. F. Sargon, J. Clin. Neurosci. 18, 391 (2011).

${ }^{9}$ F. A. Gomes, P. Teixeira, J. Azeredo, and R. Oliveira, Curr. Microbiol. 59, 118 (2009).

${ }^{10}$ J. Hasan, R. J. Crawford, and E. P. Ivanova, Trends Biotechnol. 31, 295 (2013).

${ }^{11}$ E. P. Ivanova, J. Hasan, H. K. Webb, V. K. Truong, G. S. Watson, J. A. Watson et al., Small 8, 2489 (2012).

${ }^{12}$ J. C. Tiller, C.-J. Liao, K. Lewis, and A. M. Klibanov, Proc. Natl. Acad. Sci. 98, 5981 (2001).

${ }^{13}$ S. Sandukas, A. Yamamoto, and A. Rabiei, J. Biomed. Mater. Res., Part A 97, 490 (2011).

${ }^{14}$ M. Swetha, K. Sahithi, A. Moorthi, N. Srinivasan, K. Ramasamy, and N. Selvamurugan, Int. J. Biol. Macromol. 47, 1 (2010).

${ }^{15}$ H. C. Gledhill, I. G. Turner, and C. Doyle, Biomaterials 20, 315 (1999).

${ }^{16}$ X.-X. W. Wei Ye, Key Eng. Mater. 330-332, 601 (2007).

${ }^{17}$ H. M. da Silva, M. Mateescu, C. Damia, E. Champion, G. Soares, and K. Anselme, Colloids Surf., B 80, 138 (2010).

${ }^{18}$ K. Anselme, P. Sharrock, P. Hardouin, and M. Dard, J. Biomed. Mater. Res. 34, 247 (1997).

${ }^{19}$ K. de Groot, J. G. C. Wolke, and J. A. Jansen, Proc. Inst. Mech. Eng., Part H 212, 137 (1998).
${ }^{20}$ X. Lu, B. Zhang, Y. Wang, X. Zhou, J. Weng, S. Qu et al., J. R. Soc. Interface 8, 529 (2011).

${ }^{21}$ Y. Niu, X. Liu, and C. Ding, Mater. Sci. Eng., C 28, 1132 (2008).

${ }^{22}$ J. A. N. Shepperd and H. A. Apthorp, J. Bone Joint Surg. Br. 87, 1046 (2005).

${ }^{23}$ C. Massaro, M. A. Baker, F. Cosentino, P. A. Ramires, S. Klose, and E. Milella, J. Biomed. Mater. Res. 58, 651 (2001).

${ }^{24}$ R. A. Surmenev, Surf. Coat. Technol. 206, 2035 (2012).

${ }^{25}$ L. Zhao, P. K. Chu, Y. Zhang, and Z. Wu, J. Biomed. Mater. Res., Part B 91, 470 (2009).

${ }^{26}$ E. M. Hetrick and M. H. Schoenfisch, Chem. Soc. Rev. 35, 780 (2006).

${ }^{27}$ K. Vasilev, J. Cook, and H. J. Griesser, Expert Rev. Med. Devices 6, 553 (2009).

${ }^{28}$ B. Nowack, H. F. Krug, and M. Height, Environ. Sci. Technol. 45, 1177 (2011).

${ }^{29}$ W. Chen, Y. Liu, H. S. Courtney, M. Bettenga, C. M. Agrawal, J. D. Bumgardner, and J. L. Ong, Biomaterials. 27, 5512 (2006).

${ }^{30}$ W.-H. Song, H. S. Ryu, and S.-H. Hong, J. Biomed. Mater. Res., Part A 88, 246 (2009).

${ }^{31}$ T. N. Kim, Q. L. Feng, J. O. Kim, J. Wu, H. Wang, G. C. Chen, and F. Z. Cui, J. Mater. Sci. Mater. Med. 9, 129 (1998).

${ }^{32}$ S. Suzuki, T. Fuzita, T. Maruyama, M. Takahashi, and Y. Hikichi, J. Am. Ceram. Soc. 76, 1638 (1993).

${ }^{33}$ E. Charpentier, A. I. Anton, P. Barry, B. Alfonso, Y. Fang, and R. P. Novick, Appl. Environ. Microbiol. 70, 6076 (2004).

${ }^{34}$ M. Astasov-Frauenhoffer, O. Braissant, I. Hauser-Gerspach, R. Weiger, C. Walter, N. U. Zitzmann, and T. Waltimo, J. Periodontol. 85, 349 (2014).

${ }^{35}$ O. Braissant, G. Bonkat, D. Wirz, and A. Bachmann, Thermochim. Acta 555, 64 (2013).

${ }^{36} \mathrm{R}$ Development Core Team, $R:$ A Language and Environment for Statistical Computing (R Foundation for Statistical Computing, Vienna, 2008).

${ }^{37}$ M. Kahm, G. Hasenbrink, H. Lichtenberg-Fraté, J. Ludwig, and M. Kschischo, J. Stat. Softw. 33, 1 (2010).

${ }^{38}$ G. A. Daxhelet, M. M. Coene, P. P. Hoet, and C. G. Cocito, Anal. Biochem. 179, 401 (1989).

${ }^{39}$ M. V. Berridge, P. M. Herst, and A. S. Tan, Biotechnol. Annu. Rev. 11, 127 (2005).

${ }^{40}$ T. Mosmann, J. Immunol. Methods 65, 55 (1983).

${ }^{41}$ A. Bruinink and R. Luginbuehl, Adv. Biochem. Eng. Biotechnol. 126, 117 (2011).

${ }^{42}$ See supplementary material at http://dx.doi.org/10.1116/1.4943225 for the uniaxial tensile tests and XRD analysis.

${ }^{43}$ C. O'Sullivan, P. O'Hare, N. D. O'Leary, A. M. Crean, K. Ryan, A. D. W. Dobson, and L. O’Neill, J. Biomed. Mater. Res., Part B: Appl. Biomater. 95, 141 (2010)

${ }^{44}$ R. T. Sadikot, T. S. Blackwell, J. W. Christman, and A. S. Prince, Am. J. Respir. Crit. Care Med. 171, 1209 (2005).

${ }^{45}$ A. Trampuz and W. Zimmerli, Swiss Med. Weekly 135, 243 (2005), available at http://www.smw.ch/docs/pdf200x/2005/17/smw-10934.pdf.

${ }^{46}$ R. A. Weinstein, Emerging Infect. Dis. 4, 416 (1998).

${ }^{47}$ A. F. Widmer, Clin. Infect. Dis. 33, S94 (2001).

${ }^{48}$ N. Kose, A. Otuzbir, C. Pekşen, A. Kiremitçi, and A. Doğan, Clin. Orthop. Relat. Res. 471, 2532 (2013).

${ }^{49}$ F. Lanz, X. Lanz, A. Scherly, V. Moret, A. Gaillard, P. Gruner et al., J. Neurosci. Methods 219, 262 (2013).

${ }^{50}$ Q. L. Feng, J. Wu, G. Q. Chen, F. Z. Cui, T. N. Kim, and J. O. Kim, J. Biomed. Mater. Res. 52, 662 (2000).

${ }^{51}$ A. D. Russell and W. B. Hugo, Antimicrobial activity and action of silver, in Progress in Medicinal Chemistry, edited by G. P. Ellis and D. K. Luscombe, Vol. 31 (Elsevier, Amsterdam 1994), pp. 351-370.

${ }^{52}$ I. Chopra, J. Antimicrob. Chemother. 59, 587 (2007).

${ }^{53}$ R. Behra, L. Sigg, M. J. D. Clift, F. Herzog, M. Minghetti, B. Johnston, A. Petri-Fink, and B. Rothen-Rutishauser, J. R. Soc. Interface 10, 20130396 (2013).

${ }^{54}$ A. John, H. K. Varma, and T. V. Kumari, J. Biomater. Appl. 18, 63 (2003). 